\title{
STRATEGI KRITIK CERPEN “TELINGA" TERHADAP ORBA: MENINJAU STRUKTUR PRODUKSI DAN IDEOLOGI TEKS
}

\author{
Hadi Prasetyo, Aprinus Salam \\ Magister Ilmu Sastra, Fakultas Ilmu Budaya, Universitas Gadjah Mada \\ hadiprasetyo@mail.ugm.ac.id
}

\begin{abstract}
ABSTRAK: Penelitian ini bertujuan untuk menjelaskan strategi kritik cerpen "Telinga" karya Seno Gumira Ajidarma (SGA) terhadap rezim Orde Baru (Orba) Indonesia. Hal tersebut akan dijelaskan dengan cara meninjau struktur produksi dan ideologi teks cerpen "Telinga" karya SGA. Untuk menjelaskannya, penelitian ini menggunakan teori kritik sastra materialistis Terry Eagleton. Metode yang digunakan dalam penelitian ini ialah metode dialektika. Metode ini memungkinkan peneliti untuk menjelaskan ideologi teks sebagai produk pengolahan estetik atas struktur produksi pada masa Orba. Hasil penelitian menunjukkan sebagai berikut. Pertama, cerpen "Telinga" sebagai kritik hadir dengan cara menerobos struktur produksi pada masa Orba yang selalu diatur oleh pemerintah. Struktur produksi pada masa Orba yang berkaitan dengan corak produksi umum didominasi oleh pemerintah. Segala bentuk produksi diatur sehingga muncul ideologi umum represif yang berada dalam naungan ideologi Pancasila. Hal tersebut memengaruhi corak produksi sastra yang dituntut untuk pro-pemerintah. Namun, ideologi kepengarangan SGA justru hadir sebagai bentuk resistensi kepada pemerintah sehingga ideologi estetik dalam cerpen "Telinga" berbentuk kontradiksi dengan ideologi umum pada masa Orba. Kedua, kritik cerpen "Telinga" diartikulasikan dengan ideologi teks yang hadir melalui simbol-simbol. Dalam manifestasinya, cerpen "Telinga" berhasil mengkritik Orba dengan cara menyampaikan fakta realitas tanpa harus digugat oleh pemerintah. Kritik tersebut pada gilirannya juga memanfaatkan narasi satire. Dengan demikian, cerpen "Telinga" sebagai kritik dinaturalisasikan melalui ruang estetik untuk mengungkap fakta yang dibungkam pada masa Orba.

KATA KUNCI: Struktur produksi; estetik; ideologi teks; Orde Baru (Orba); Terry Eagleton
\end{abstract}

\section{"TELINGA" SHORT STORY CRITICISM STRATEGY TOWARDS THE ORBA: REVIEWING PRODUCTION STRUCTURE AND IDEOLOGY OF THE TEXT}

\begin{abstract}
This research aims to explain the strategy of "Telinga" short story by Seno Gumira Ajidarma (SGA) towards the Indonesian New Order (Orba) regime. It will be explained by reviewing the production structure and ideology of the text of "Telinga" short story by SGA. This research uses Terry Eagleton's literature's materialistic criticism theory. The method used in this research is the dialectical method. This method allows the researcher to explain the ideology of the text as a product of aesthetic processing of the production structure during the Orba era. The results showed the following. First, "Telinga" short story as a criticism comes by breaking through the production structure during the Orba era which was always regulated by the government. The production structure during the Orba era related to the general mode of production was dominated by the government. All forms of production are regulated in order that a repressive general ideology emerges under the auspices of the Pancasila ideology. This affected the literary mode of production which was demanded to support the government. However, the SGA's authorship ideology actually exists as a form of resistance againts the government in order that the aesthetic ideology in "Telinga" short story contradicts the general ideology during the Orba era. Second, "Telinga" short story criticism is articulated with the ideology of the text which is present through symbols. In its manifestation, "Telinga" short story successfully criticizes the Orba regime by delivering reality-based fact without any accusation by government. The critic on its turn also applies satire narracy. Therefore, "Telinga" short story as criticism naturalized through an aesthetic space to reveal silenced fact during the Orba era.
\end{abstract}

KEYWORDS: Production structure; aesthetic; ideology of the text; New Order (Orba); Terry Eagleton

\begin{tabular}{lccc}
\hline Diterima: & Direvisi: & Distujui: & Dipublikasi: \\
2021-06-22 & 2021-07-05 & $2021-07-07$ & $2021-10-29$ \\
Pustaka & & & \\
& & & \\
& MENINJAU STRUKTUR PRODUKSI DAN IDEOLOGI TEKS. Fon: Jurnal Pendidikan \\
& Bahasa dan Sastra Indonesia, 17(2), 122-134. doi:https://doi.org/10.25134/fon.v17i2.4329 \\
\hline
\end{tabular}


Program Studi Pendidikan Bahasa dan Sastra Indonesia FKIP Universitas Kuningan

\section{PENDAHULUAN}

Seno Gumira Ajidarma (kemudian disebut SGA) merupakan salah satu sastrawan di Indonesia yang sebagian besar karyanya berakar dari proses jurnalistik. Melalui hal tersebut, SGA sering kali mencoba menyuarakan fakta realitas. Salah satunya ialah fakta yang terjadi pada masa Orde Baru (Orba). Fakta yang coba diungkap oleh SGA pada masa Orba ialah insiden di Dili, Timor Timur, yang terjadi pada tahun 1991. Pada saat itu, insiden di Dili banyak menelan korban jiwa.

Sebagai seorang jurnalis, SGA dapat dianggap berani mengungkap fakta tersebut di tengah pemerintahan otoriter. Namun, pada akhirnya, SGA dipecat dari majalah Jakarta Jakarta karena "keberaniannya". Melalui kejadian tersebut, secara langsung maupun tidak langsung rezim Orba menghadirkan sistem politik negara yang diselenggarakan dengan cara ketat atau biasa disebut dalam koordinasi pengawasan. Kekuasaan pada saat itu berlangsung dalam kondisi sangat kuat sehingga masyarakat tidak memiliki kebebasan berpendapat (Salam dan Akmal, 2014, hlm. 68).

Selanjutnya, kondisi demikian tidak cukup kuat menghentikan langkah SGA untuk mencoba menyuarakan fakta realitas yang coba disembunyikan atau dibungkam oleh kekuasaan otoriter. Ia mencoba cara lain dengan menulis karya sastra. Kurnia (2002, hlm. 17) menyatakan bahwa karya SGA merupakan bentuk jurnalisme sastra karena memuat fakta-fakta yang telah dirancang dalam urutan adegan, percakapan, dan amatan suasana. Salah satu karya yang ditulis oleh SGA untuk mengungkap fakta ialah cerpen "Telinga".

Penulisan cerpen "Telinga" terinspirasi dari laporan majalah Jakarta Jakarta bahwa sebelum terjadinya insiden di Dili, penduduk sudah sering mendapat teror dari gerombolan orang berambut gondrong yang suka masuk rumah dan menculik penghuninya. Pada akhir
Oktober 1991, Gubernur Timor Timur, Mario Viegas Carrascalao, menerima tamu (empat pemuda) yang dua di antara empat pemuda itu telinganya telah terpotong akibat perlakuan gerombolan penculik (Ajidarma, 2010, hlm. 334).

Gambaran visual mengenai "telinga yang dipotong" itulah yang kemudian mengilhami SGA menulis cerpen "Telinga" sebagai cara lain untuk menyuarakan fakta dan mengkritik pemerintahan otoriter Orba. Pertanyaan yang kemudian muncul dari hal tersebut ialah bagaimana cerpen "Telinga" sebagai sebuah medium mengungkap fakta realitas dan kritik ideologis dihadirkan untuk melakukan dan memantik resistensi terhadap kekuasaan otoriter Orba? Pertanyaan tersebut tampaknya terekam melalui pernyataan SGA dalam esainya berjudul "Kehidupan Sastra di dalam Pikiran" sebagai berikut.

Ketika jurnalisme dibungkam, sastra harus bicara. Karena bila jurnalisme bicara dengan fakta, sastra bicara dengan kebenaran. Fakta-fakta bisa diembargo, dimanipulasi, atau ditutup dengan tinta hitam, tapi kebenaran muncul dengan sendirinya, seperti kenyataan (Ajidarma, 2010, hlm. 325).

Melalui kutipan esai di atas, cerpen "Telinga" sebagai karya sastra berusaha menawarkan kritik dengan mengungkapkan fakta yang terjadi semasa Orba. Sastra dianggap sebagai sarana penyampaian kebenaran (fakta) yang sesuai dalam konteks kekuasaan otoriter. Selain itu, pertanyaan di atas tampaknya juga terekam melalui prosedur kritik ideologi Marxis klasik yang cenderung bersifat symptomatic-interpretasi terhadap gejala (symptom) yang menyembunyikan realitas di baliknya (Eagleton, 1983, hlm. 1). Dalam konteks sastra, ideologi ini kemudian dapat 
Program Studi Pendidikan Bahasa dan Sastra Indonesia FKIP Universitas Kuningan

dipertentangkan melalui proses kepengarangan yang menunjukkan bahwa pengarang mengupayakan teks sastra sebagai kritik terhadap ideologi dengan ideologi pengarang sendiri.

Eagleton (1998,

hlm. 44) mengatakan bahwa teks sastra tidak bersifat pasif, tetapi secara aktif berperan untuk menentukan proses produksi dan struktur-struktur ideologi yang membentuknya. Karya sastra menghadirkan kompleksitas realitas kehidupan manusia di dalam masyarakat. Akan tetapi, hubungan antara karya sastra dengan kehidupan manusia dalam masyarakat tidak dapat dipahami secara langsung. Oleh karena itu, karya sastra biasanya dianggap sebagai sebuah produk yang tidak mempunyai otonomi dan tidak mempunyai sifat formatif terhadap masyarakat.

Pandangan ini didebat oleh Gramsci. Gramsci mengakui bahwa karya sastra memiliki fungsi otonom dan formatif terhadap masyarakat. Hal tersebut terutama ditemukan dalam teori kultural/ideologis general Gramsci yang kemudian diterapkan dalam sastra (Faruk, 2010, hlm. 130). Artinya, setiap karya sastra yang ditulis oleh pengarang pada dasarnya dipengaruhi oleh ideologi yang melatarbelakangi kemunculannya.

Selanjutnya, Marx menyatakan bahwa sastra bersifat ideologis sekaligus berada dalam lingkaran ideologis (Eagleton, 1998, hlm. 80). Dengan demikian, dapat dikatakan bahwa ideologi merupakan relasi antara teks dengan realitas. Namun, kajian terhadap sastra pada umumnya hanya berada dalam ruang lingkup pembacaan yang sekadar memaknai suatu karya yang telah selesai dan siap untuk dikonsumsi. Pernyataan tersebut kemudian disanggah oleh Eagleton. Ia menyetujui pendapat Althusser mengenai pentingnya pemahaman terhadap praktik sosial dengan melibatkan proses yang terjadi-tidak hanya melihat pada hasil atau produk (Bennet, 2003, hlm. 122). Oleh karena itu, untuk menghindari pembacaan (sekaligus pemaknaan) demikian, penelitian terhadap cerpen "Telinga" berupaya menawarkan pembacaan terhadap karya sastra sebagai praktik material (kritik materialistis).

Teks sastra bukanlah ekspresi ideologi, tetapi teks sastra lebih tepat dikatakan sebagai produksi ideologi tertentu. Oleh karena itu, kajian teks sastra seharusnya meliputi elemen-elemen eksternal (struktur produksi) dan elemen internal. Struktur produksi teks sastra meliputi konstituen-konstituen ideologi, seperti corak produksi umum (CPU), ideologi umum (IU), corak produksi sastra (CPS), ideologi kepengarangan (IK), dan ideologi estetik (IE). Sementara itu, elemen internal teks merujuk pada ideologi teks yang ditransformasikan dari elemen eksternal (Eagleton, 1998, hlm. 44-63).

Corak produksi umum (CPU) dipahami sebagai kesatuan beberapa kekuatan dan relasi sosial produksi material. Kekuatan produksi dipahami sebagai bahan, alat, dan teknik produksi, sedangkan relasi sosial produksi merupakan posisi yang menunjukkan hubungan seseorang dengan unsur-unsur kekuatan produksi dan hubungan yang mengatur interaksi pihak yang terlibat dalam proses produksi. Dengan demikian, CPU tidak dapat dipisahkan dengan kondisi ekonomi yang menjadi basis kekuatan produksi.

Ideologi umum (IU) didefinisikan sebagai segenap wacana yang relatif koheren tentang nilai, representasi, dan keyakinan. Hal tersebut diwujudkan dalam perangkat material dan hubungan konkret antara subjek-subjek individu dengan kondisi sosialnya. IU merupakan ideologi yang berkembang di satu formasi sosial tertentu yang memengaruhi individuindividu yang ada di dalamnya secara kuat.

Corak Produksi Sastra (CPS) dipahami sebagai kesatuan beberapa 
Program Studi Pendidikan Bahasa dan Sastra Indonesia FKIP Universitas Kuningan

kekuatan dan relasi sosial produksi sastra dalam formasi sosial tertentu. Di dalam CPS terdapat komponen tertentu, seperti media, penerbitan, distribusi, pertukaran, dan konsumsi.

Ideologi kepengarangan

merupakan efek cara pengarang menyisipkan biografinya ke dalam IU. IK ditentukan oleh faktor-faktor yang berbeda, seperti sosial, gender, kebangsaan, agama, letak geografis, dan sebagainya.

Ideologi estetik (IE) berhubungan dengan formasi internal yang kompleks. IE merupakan wilayah estetik spesifik dari ideologi umum yang diartikulasikan dengan wilayah lainnya, seperti etika, agama, dan hubungannya dengan dominasi dan subordinasi. Pada akhirnya, IE ditentukan oleh CPU. IE berfungsi untuk memediasi dengan istilah-istilah estetiknya antara IU dengan IK dalam mentransformasikan relasi keduanya.

Sementara itu, ideologi teks mengacu pada elemen internal yang berpengaruh dalam terciptanya teks melalui karakter tertentu yang memiliki relasi dengan ideologi dan sejarah. Teks bukanlah produk tunggal dari satu individu dan juga bukan dimaknai sebagai ruang ekspresi pengarangnya. Teks sastra yang ditulis oleh pengarang mengandung muatan ideologi yang harus dipahami sebagai hasil dari rangkaian peristiwa yang panjang. Alderson (2004, hlm. 47) menyatakan bahwa teks tidak semata-mata dibaca sebagai ungkapan pengarangnya, meskipun pengarang merupakan orang yang berperan penting dalam penentuan ideologi teks.

Berdasarkan penelusuran penulis, terdapat beberapa penelitian terdahulu tentang karya-karya SGA dan penelitianpenelitian terdahulu menggunakan kajian kritik materialistis Terry Eagleton. Pertama, Tempo (2013) melakukan penelitian berjudul "Kekerasan Personal dalam Cerpen "Jakarta, Suatu Ketika"
Karya Seno Gumira Ajidarma". Penelitian ini mencoba menjelaskan kekerasan personal yang terdapat dalam cerpen dengan pendekatan sosiologi sastra.

Kedua, Sunanda (2015) melakukan penelitian berjudul "Pandangan Masyarakat tentang Sistem Kekuasaan Sosial dan Politik". Dalam penelitian ini, Sunanda mengkaji pandangan masyarakat terhadap gaya kepemimpinan Soeharto pada rezim Orde Baru yang terdapat dalam cerpen "Paman Gober" karya Seno Gumira Ajidarma dengan perspektif strukturalisme genetik.

Ketiga, terdapat penelitian berjudul "Representasi Kekuasaan Negara dalam Cerpen Seno Gumira Ajidarma Sebelum dan Sesudah Reformasi: Analisis Gramscian". Penelitian yang ditulis oleh Turama (2016) ini menunjukkan hasil bahwa dalam cerpen "Saksi Mata" dan "Aku, Pembunuh Munir" ada degradasi hegemoni yang dilakukan oleh negara. Masyarakat tidak sepenuhnya lagi menerima dominasi negara dengan cara mempermainkan dan memutarbalikkan lambang negara.

Keempat, terdapat penelitian berjudul "Cerpen "Matinya Seorang Penari Telanjang" Karya Seno Gumira Ajidarma dalam Perspektif Subjek Slavoj Žižek. Penelitian yang dilakukan oleh Zamzuri (2018) ini menghasilkan bahwa subjek melakukan tindakan radikal dengan menjadi penari telanjang. Hal tersebut, bagi Zamzuri, merupakan tindakan melawan dimensi simbolik atau sosial.

Kelima, Akbar (2019) melakukan penelitian berjudul "Kritik Sosial atas Rezim Orde Baru dalam Kumpulan Cerpen Penembak Misterius Karya Seno Gumira Ajidarma: Kajian Sosiologi Sastra Marx". Penelitian ini menghasilkan kesimpulan bahwa terdapat kritik terhadap modernitas serta kritik terhadap pembunuhan, penculikan, dan penembakan.

Keenam, Purnamawati, Sangidu, Manshur, dan Dardiri (2019) melalukan 
Program Studi Pendidikan Bahasa dan Sastra Indonesia FKIP Universitas Kuningan

penelitian terhadap Antologi Puisi $F \bar{l}$ Tarīqi Al-Fajri Karya Abdullah AlBaradduni. Hasilnya, berdasarkan kritik materialistis, puisi dipilih sebagai genre untuk mengungkapkan ideologi perlawanan. Perlawanan dalam antologi puisi tersebut ialah perlawanan rakyat terhadap pemerintahan imamah.

$$
\text { Ketujuh, Djunuhi }
$$

menerapkan kritik materialistis terhadap novel Perempuan Berkalung Sorban (PBS) karya Abidah El-Khalieqy. Dalam penelitiannya, Djunuhi menunjukkan hasil bahwa novel PBS telah melewati proses produksi material eksternal. Selain itu, ideologi PBS berhubungan dengan insiden-insiden historis untuk mengkritik masyarakat komunal pesantren yang identik dengan ideologi patriarki.

Dengan demikian, berdasarkan tinjauan terhadap beberapa penelitian terdahulu, penulis mencoba menawarkan sebuah penelitian yang berbeda. Penelitian ini akan menjelaskan cerpen "Telinga" sebagai kritik terhadap Orba. Dalam prosesnya, struktur produksi dan ideologi teks cerpen "Telinga" perlu diselisik lebih jauh. Untuk menjelaskan hal tersebut, penulis akan menggunakan teori kritik sastra materialistis Terry Eagleton yang mencakup elemen eksternal dan elemen internal teks.

\section{METODE}

Menurut Faruk (2015, hlm. 55) metode penelitian adalah cara untuk memperoleh pengetahuan mengenai objek tertentu dan harus sesuai dengan kodrat keberadaan objek itu sebagaimana yang dinyatakan oleh teori. Metode yang digunakan dalam penelitian ini ialah metode dialektika. Dengan menggunakan metode dialektika, penelusuran unsurunsur fiksi dalam cerpen dikaitkan ke dalam bangunan faktual dan sebaliknya. Dengan demikian, metode ini memungkinkan peneliti untuk melihat teks (karya sastra) sebagai produk yang tidak serta-merta selesai dan siap untuk dikonsumsi. Artinya, dalam proses penciptaan karya terdapat pengaruh eksternal.

Tahapan-tahapan yang ditempuh dalam penelitian ini adalah: 1) menentukan objek material penelitian, yaitu cerpen "Telinga" karya SGA dan melakukan pembacaan dari awal hingga akhir secara saksama untuk mendapatkan gambaran makna mengenai cerpen tersebut; 2) merumuskan masalah penelitian berdasarkan kecenderungan masalah yang muncul dalam cerpen "Telinga"; 3) menentukan objek formal penelitian, yaitu teori kritik sastra materialistis Terry Eagleton; 4) mencatat data berupa beberapa kutipan cerpen "Telinga" yang merujuk pada rumusan masalah penelitian; 5) melakukan analisis terhadap cerpen "Telinga"; 6) menyajikan hasil analisis dalam bentuk laporan penelitian berupa artikel; serta 7) menarik kesimpulan dari hasil penelitian yang telah dilakukan.

\section{HASIL DAN PEMBAHASAN}

Sebagaimana telah dikemukakan pada bagian pendahuluan, penelitian ini mencoba menjelaskan strategi kritik cerpen "Telinga" terhadap rezim Orba. Untuk menjelaskannya, penulis akan menguraikan struktur produksi yang melingkupi proses penciptaan cerpen "Telinga" dan ideologi teksnya.

\section{Struktur Produksi Sastra: Kekuasaan Otoriter Orba}

Corak produksi umum (CPU) dipahami sebagai kesatuan beberapa kekuatan dan relasi sosial produksi material. CPU tidak dapat dipisahkan dengan kondisi ekonomi yang menjadi basis kekuatan produksi. Dalam hal ini, kondisi tersebut terekam pada masa Orde Baru. CPU pada masa Orba didominasi oleh kekuasaan otoriter. Kekuasaan rezim tersebut menyusun Rencana Pembangunan Lima Tahun (Repelita). Pada masa itu pula 
Program Studi Pendidikan Bahasa dan Sastra Indonesia

FKIP Universitas Kuningan

Soeharto berupaya menjaga kestabilan kondisi sosial-politik agar kondusif untuk pembangunan ekonomi. Selain itu, depolitisasi masyarakat menjadi penting bagi kestabilan pembangunan ekonomi (Fuller, 2011, hlm. 51; Faruk, 2010). Heryanto (1990, hlm. 290) juga menegaskan bahwa "pembangunan" merupakan tantangan serius selama masa Orba. Melalui hal tersebut, dapat dikatakan bahwa masa Orba melangsungkan pemulihan ekonomi.

Ironisnya, kondisi tersebut justru menyebabkan ketidakpuasan di kalangan masyarakat Indonesia karena pemerintah dianggap terlalu fokus untuk menarik investor asing. Selain itu, kesempatankesempatan investasi besar hanya diberikan kepada orang Indonesia yang biasanya merupakan perwira militer atau sekelompok kecil warga keturunan Tionghoa. Hal ini menimbulkan konglomerasi dan bisnis yang erat dengan korupsi, kolusi, dan nepotisme (KKN).

$$
\text { Sebagai }
$$$$
\text { contoh, }
$$

selama

pemerintahan Orba, korupsi di Indonesia semakin meningkat. Berbagai sektor dalam pemerintahan tidak luput dari korupsi. Melalui keadaan seperti itu, para penguasa menjadi semakin diuntungkan, sedangkan rakyat semakin dirugikan. CPU pada masa Orba menyebabkan pula pembangunan yang bersifat terpusat dan tidak merata. Pembangunan hanya mengutamakan pertumbuhan ekonomi tanpa diimbangi kehidupan politik, ekonomi, serta sosial yang demokratis dan adil. Hal ini juga berimbas pada bentuk kebudayaan yang semakin dibayang-bayangi oleh kekuasaan otoriter. Pada akhirnya, "pembangunan" meleburkan dan membatasi pertumbuhan bentuk-bentuk kesenian yang menampilkan gagasan-gagasan alternatif terhadap segala hal tentang Orba.

Kondisi CPU seperti di atas menjadi basis berkembangnya ideologi dominan atau ideologi umum (IU) pada masa Orba. IU dipahami sebagai segenap wacana yang relatif koheren tentang nilai, representasi, dan keyakinan. IU merupakan ideologi yang berkembang pada satu formasi sosial tertentu yang memengaruhi individuindividu yang ada di dalamnya secara kuat.

Hal tersebut tampak terlihat pada pemerintahan Orba yang menganut ideologi Pancasila. Segala bentuk peraturan yang diberlakukan berdasar lima asas dalam Pancasila. Nahasnya, ideologi Pancasila yang berlaku pada masa tersebut justru menjadi dasar pengawasan represif yang dilakukan oleh militer. Menurut Schwarz (1994, hlm. 10), Pancasila telah menjadi satu agen pemaksaan persatuan sebuah bangsa yang masih muda dan alat penindasan yang kuat. Misalnya, melalui IU yang berkembang, militer mengambil peranan penting dalam rangka menjaga stabilitas nasional.

Dengan ideologi Pancasila, rezim Orba membasmi setiap gerakan separatis, seperti Fretilin (gerakan prokemerdekaan Timor Timur). Dalam hal ini, IU yang berlaku menjadi sarana legitimasi kekuasaan otoriter sehingga rakyat "dipaksa" berperan aktif dalam CPU sosial-ekonomi. Namun, perlu ditegaskan bahwa IU yang berlaku pada masa Orba tidak mutlak menjadi ideologi satusatunya. IU tersebut hanya menjadi ideologi dominan bagi ideologi-ideologi lain yang terdapat dalam struktur sosialekonomi.

Arus perkembangan CPU dan IU yang telah dijelaskan selanjutnya memengaruhi Corak Produksi Sastra (CPS) pada masa Orba. CPS dipahami sebagai kesatuan beberapa kekuatan dan relasi sosial produksi sastra dalam formasi sosial tertentu. Di dalam CPS terdapat komponen tertentu, seperti media, penerbitan, distribusi, pertukaran, dan konsumsi. CPS yang mengikuti arus perkembangan CPU dan IU pada masa Orba menimbulkan relasi antara penguasa, penerbit, dan pengarang. Relasi tersebut membuat penerbit melakukan kontrol 
Program Studi Pendidikan Bahasa dan Sastra Indonesia FKIP Universitas Kuningan

terhadap karya-karya yang akan diterbitkan, seperti penyensoran terhadap berita-berita yang dapat merugikan kekuasaan rezim.

Produksi karya sastra pada masa Orba cenderung memainkan cara aman dengan membuat karya sastra bertemakan percintaan. Hal tersebut terjadi karena pengarang menciptakan karya sastra dalam rambu-rambu yang dilegitimasi oleh pemerintahan. Artinya, karya sastra yang hadir di panggung sastra Indonesia pada masa tersebut justru gagal menghadirkan karya yang berkenaan dengan cinta dan sebagainya secara filosofis. Karya yang hadir pada masa itu justru karya-karya pop yang sesuai dengan keinginan para ideolog Orba (Maier, 1999, hlm. 253).

Selain itu, publikasi majalah tidak hanya berdasar pada penerbit-penerbit kecil, tetapi berpindah haluan pada penerbit-penerbit besar. Salah satunya ialah majalah Jakarta Jakarta, tempat SGA bekerja sebagai redaktur pelaksana. Dengan keberaniannya, SGA memberitakan kejadian Dili melalui majalah Jakarta Jakarta. Tulisan dalam majalah tersebut mengundang reaksi sehingga SGA dipanggil oleh Pusat Penerangan Pertahanan dan Keamanan ABRI di Cilangkap.

Pada pertemuan itu, tulisan yang termuat dalam majalah Jakarta Jakarta dianggap penuh dramatisasi dan mendiskreditkan pihak militer. Pada akhirnya, pertemuan tersebut berujung pada pencekalan terhadap SGA. Dengan adanya pencekalan tersebut, terlihat CPS yang dipengaruhi oleh CPU dan IU menghasilkan penerbit majalah yang berpihak pada kekuasaan otoriter. Namun, atas kejadian tersebut, SGA tidak kehabisan cara untuk mengungkap fakta yang dibungkam.

Dalam suasana serba dikontrol, SGA mencoba cara lain untuk menyuarakan fakta realitas, yaitu dengan menulis karya sastra. Salah satunya ialah cerpen
"Telinga". Cerpen tersebut dikemas oleh SGA dengan narasi satire, tetapi tetap menyimbolkan insiden yang terjadi di Dili, seperti simbol "darah" dan "telinga". Alhasil, cerpen ini pertama kali dipublikasikan oleh surat kabar KOMPAS pada 9 Agustus 1992. Melalui surat kabar KOMPAS, SGA mampu keluar dari bayang-bayang CPS pada masa Orba. Artinya, dengan menulis cerpen "Telinga", SGA menjadi sensor untuk karyanya sendiri. Bagi Fuller (2011, hlm. 54), SGA telah melalukan self-censorship.

Kondisi CPS yang begitu didominasi oleh peran CPU dan IU menciptakan ideologi kepengarangan (IK) SGA pada masa Orba. IK merupakan efek cara pengarang menyisipkan biografinya ke dalam IU yang ditentukan oleh faktorfaktor yang berbeda, seperti sosial, gender, kebangsaan, agama, letak geografis, dan sebagainya. Artinya, partisipasi pengarang dalam menciptakan karya sastra tidak terbatas pada partisipasi kreatif dan aktivitas intelektual, tetapi meliputi totalitas kehidupan praktis, termasuk konstruksi pengalaman dan religiusnya.

Pada masa Orba, telah dipahami bahwa kekuasaan berdiri dalam kondisi otoriter sehingga masyarakat tidak memiliki kebebasan untuk menyuarakan aspirasinya secara terbuka. Kondisi seperti itu juga dialami oleh para sastrawan. Mereka menulis karya sastra dalam ramburambu yang dilegitimasi oleh pemerintahan. Kondisi tersebut membuat para pengarang terkungkung oleh dominasi IU Orba. Akan tetapi, SGA melalui karyakaryanya selalu melakukan perlawanan dan kritik terhadap pemerintah. Hal tersebut tidak terlepas dari latar belakang kehidupan SGA.

Secara biografi, kehidupan SGA bertolak belakang dengan kehidupan ayahnya yang merupakan guru besar Fakultas MIPA, UGM. Setelah lulus SMP, SGA tidak mau melanjutkan sekolah. Ia terpengaruh oleh cerita petualangan Old 
Program Studi Pendidikan Bahasa dan Sastra Indonesia FKIP Universitas Kuningan

Shatterhand sehingga membuatnya mengembara, mulai dari Jawa Barat, Sumatera, hingga Medan. Karena kehabisan uang, ia menghubungi ibunya untuk meminta uang. Akan tetapi, ibunya justru mengirim tiket untuk pulang. Oleh karena itu, SGA pulang dan meneruskan sekolah.

SGA memilih bersekolah di SMA Kolese De Britto yang memperbolehkan siswa tidak memakai seragam. Sementara itu, komunitas yang dipilih sesuai dengan jiwanya. Bukan teman-teman di lingkungan elite perumahan dosen Bulaksumur (UGM), rumah orang tuanya. Akan tetapi, komunitas anak-anak jalanan yang suka tawuran. Ia juga ikut teater Alam pimpinan Azwar A.N selama dua tahun. Pada usia 19 tahun, SGA menikah dan bekerja sebagai wartawan. Pada tahun itu juga SGA berkuliah di Institut Kesenian Jakarta, jurusan Sinematografi. Ia menjadi seniman karena terinspirasi oleh Rendra yang santai, bisa bicara, hura-hura, nyentrik, dan berambut gondrong.

Melalui biografi SGA tersebut, tampak bahwa perjalanan hidup yang dilalui oleh SGA membentuk cara berpikirnya. Dapat dikatakan bahwa SGA merupakan representasi orang yang sukar diatur. Oleh karena itu, ketika bekerja, ia selalu berpindah-pindah sampai pada akhirnya bekerja untuk majalah Jakarta Jakarta. Akan tetapi, IK SGA dengan IU Orba tampak berkontradiksi. IK SGA ialah untuk mengkritik pemerintahan Orba, sementara IU bersifat antikritik. Akibatnya, kritik SGA yang secara terangterangan pada majalah Jakarta Jakarta dicekal. Oleh karena itu, SGA menciptakan cerpen "Telinga" sebagai kritik terhadap Orba. Cerpen tersebut telah dikemas melalui simbolisme dalam narasi satire sehingga dapat lolos dari pengawasan IU Orba.

Pada akhirnya, muara elemen eksternal sebagai proses terciptanya karya sastra ialah ideologi estetik (IE). IE berhubungan dengan formasi internal yang kompleks yang di dalamnya terdapat beberapa subsektor, salah satunya ialah sastra. IE merupakan wilayah estetik spesifik dari IU yang diartikulasikan dengan wilayah lainnya, seperti etika, agama, dan hubungannya dengan dominasi dan subordinasi; pada akhirnya ditentukan oleh CPU.

Dalam perkembangan karya sastra pada masa Orba, sastrawan menulis novel di bawah rambu-rambu kompromi dan sangat hati-hati. Hal ini disebabkan oleh kekuasaan otoriter yang tidak membebaskan setiap orang menyampaikan aspirasinya secara terus terang. Artinya, terdapat pengawasan represif sehingga pengarang cenderung menciptakan karya sastra melalui tema-tema percintaan. Pada akhirnya, kemunculan karya sastra pada masa Orba terkesan dituntut "melupakan" wilayah realitas yang melingkupi pengarang.

Meskipun berproses dalam keadaan penuh pengawasan, SGA justru tumbuh menjadi pengarang melalui kontemplasi realitas yang melingkupinya. Dalam penelitian ini, munculnya cerpen "Telinga" yang ditulis oleh SGA pada masa otoriter Orba tidak terlepas dari relasi-relasi dengan faktor-faktor lain. Cerpen "Telinga" ditulis karena ada keterkaitan relasi antara IU dalam CPU Orba dengan IK SGA. Dalam hal ini, cerpen "Telinga" berpola kontradiksi, yaitu bersifat resisten untuk mengkritik pemerintahan Orba. SGA sebagai sastrawan (dan) jurnalis mengutamakan narasi dan penyampaian kisah-kisah. Cerpen "Telinga" dikonstruksi oleh SGA dengan kategori estetik, yaitu simbol-simbol dalam narasi satire. Hal tersebut memediasi bentuk kontradiksi antara IK SGA dengan IU Orba. Sebagai contoh, dalam cerpen "Telinga", narasi awal ditulis sebagai berikut. 
Program Studi Pendidikan Bahasa dan Sastra Indonesia FKIP Universitas Kuningan

"Ceritakanlah kepadaku tentang kekejaman,” kata Alina kepada juru cerita itu.

Maka, juru cerita itu pun bercerita tentang telinga. (Ajidarma, 2016, hlm. 13)

Dari kutipan cerpen "Telinga" di atas, hadir simbol "telinga" sebagai representasi "kekejaman" pada masa Orba. Simbol tersebut dinarasikan dengan satire sebagai ruang estetik. Namun, narasi awal dalam cerpen tersebut tidak mengurangi esensi awal bersifat kontradiksi untuk mengkritik IU Orba, yaitu memperlihatkan fakta realitas insiden di Dili, Timor Timur. Melalui simbol-simbol, seperti "telinga", "tetesan darah", "medan perang", dan sebagainya, cerpen "Telinga" mencoba membongkar fakta yang disembunyikan atau dibungkam pada masa Orba, yaitu insiden di Dili, Timor Timur.

IE dalam cerpen "Telinga" yang memediasi struktur produksi yang ada di luar teks pada gilirannya "lulus sensor" sebagai kritik terhadap pemerintahan Orba. Dengan demikian, dalam hal ini, IE berperan penting dalam menciptakan dan memproduksi karya sastra. IE memediasi CPU, CPS, IU, dan IK pada masa Orba.

\section{Menguraikan Ideologi Teks: Kritik Cerpen "Telinga" terhadap Orba}

Kehadiran karya sastra merupakan produk yang dibentuk oleh hubungan dialektika antara elemen eksternal dengan elemen internal. Analisis terhadap struktur produksi (elemen eksternal) yang telah dijelaskan pada bagian sebelumnya memengaruhi kehadiran ideologi teks (elemen internal) cerpen "Telinga" karya SGA. Ideologi teks merupakan elemen internal yang menentukan terbentuknya teks dalam karakter tertentu. Ideologi teks bukanlah ideologi kepengarangan yang termuat dan diekspresikan oleh pengarang di dalam teks. Ideologi teks adalah teks itu sendiri, yaitu hasil transformasi atau pengolahan estetik pengarang (SGA) atas struktur produksi yang saling memengaruhi.

Konstruksi cerpen "Telinga" dibentuk menggunakan alat-alat produksi teks yang berupa kategori estetik. Alat produksi teks menghasilkan konstruksi cerpen "Telinga" yang di dalamnya termuat tema, tokoh, dan peristiwa yang disimbolkan oleh SGA. Konstruksi cerpen tersebut berkaitan dengan ideologi dan fakta realitas pada masa Orba. Dengan demikian, teks mengimplikasikan ideologi dan mengacu pada fakta sejarah. Oleh karena itu, pada bagian ini akan dibahas hubungan antara teks dengan ideologi dan relasinya dengan fakta realitas pada masa Orba.

Dalam hal ini, SGA sebagai produsen bertindak mengolah material mentah teks menjadi sebuah produk teks (cerpen "Telinga"). Teks yang diproduksi oleh hadir melalui pengolahan estetik dengan narasi satire. Senada dengan hal tersebut, Rampan (2001, hlm. 24) menyatakan bahwa karya fiksi Seno menerjemahkan kejadian-kejadian dengan satire dan ironi. Melalui produksi teks tersebut, SGA menghasilkan cerpen "Telinga" sebagai sebuah kritik terhadap rezim otoriter Orba. Sementara itu, dalam melihat keterkaitan teks dengan ideologi, teks perlu dianalisis untuk menemukan signifikansi ideologi dan relasinya dengan fakta realitas.

Bangunan cerpen "Telinga" dikonstruksi dengan simbol-simbol yang secara estetik muncul di dalam teks. Simbol-simbol tersebut dihadirkan dengan diksi-diksi yang diolah dalam narasi satire sebagaimana tergambar pada kutipan cerpen di bawah ini.

\section{"Ceritakanlah kepadaku tentang kekejaman,” kata Alina kepada juru cerita itu.}


Program Studi Pendidikan Bahasa dan Sastra Indonesia FKIP Universitas Kuningan

Maka, juru cerita itu pun bercerita tentang telinga. (Ajidarma, 2016, hlm. 13)

Berdasarkan kutipan di atas, diksi "kekejaman" disimbolkan dengan diksi "telinga". Hal tersebut mengimplikasikan kritik cerpen "Telinga" terhadap IU Orba yang terkesan kejam (represif) kepada rakyat. Bentuk dominasi IU disimbolkan melalui diksi "telinga" yang mengacu pada fakta realitas. Melalui esainya berjudul "Tentang Empat Cerpen", SGA menerangkan bahwa gubernur Timor Timur mendapati empat pemuda di kantornya yang dua dari empat pemuda itu telinga sudah terpotong (Ajidarma, 2010, hlm. 334). Dalam hal ini, cerpen "Telinga" dimanfaatkan untuk mereproduksi fakta realitas tersebut. Pada gilirannya, melalui cerpen "Telinga", kritik dengan mudah dilancarkan kepada pemerintahan Orba. Kritik tersebut dikemas dengan karya sastra agar tidak terjadi benturan dengan IU Orba. Selain narasi awal yang termuat dalam cerpen "Telinga" di atas, ideologi teks juga menghasilkan narasi satire. Hal tersebut terlihat pada kutipan berikut ini.

Kukirimkan telinga ini untukmu, Dewi, sebagai kenang-kenangan dari medan perang. Ini adalah telinga seseorang yang dicurigai sebagai mata-mata musuh. Kami memang biasa memotong telinga orang-orang yang dicurigai sebagai peringatan atas risiko yang mereka hadapi jika menyulut pemberontakan. Terimalah telinga ini, hanya untukmu, kukirimkan dari jauh karena aku kangen padamu. Setiap kali melihat telinga ini, ingatlah diriku yang kesepian. Memotong telinga adalah satusatunya hiburan. (Ajidarma, 2016, hlm. 13-14)
Narasi satire di dalam cerpen tersebut mengartikulasikan sebuah keresahan terhadap rezim Orba yang sewenang-wenang melalukan tindakan represif. Narasi satire tersebut kemudian dapat pula digunakan untuk melakukan perlawanan terhadap pemerintah. Selain itu, kritik cerpen "Telinga" terhadap pemerintah dibungkus dalam bentuk surealis, seperti memotong telinga adalah satu-satunya hiburan.

Cerpen "Telinga" sebagai kritik terhadap Orba juga dibungkus melalui tema percintaan. Hal ini menjadi sebuah strategi yang paling aman karena tema percintaan merupakan tema karya sastra yang dapat dikonsumsi oleh semua orang dan "direstui" oleh pemerintah. Akan tetapi, alih-alih ikut melegitimasi tema tersebut, cerpen "Telinga" justru memuat simbol-simbol kekejaman Orba yang secara estetik memunculkan ideologi teks. Artinya, dapat dikatakan bahwa dengan balutan tema percintaan, cerpen "Telinga" sebagai sebuah kritik justru berhasil lolos dari kungkungan sensor pemerintah.

Ideologi teks dalam cerpen "Telinga" juga menghadirkan kritik melalui simbol "darah". Hal tersebut tampaknya sesuai dengan fakta realitas yang terjadi pada masa Orba, sebagaimana tergambar dalam kutipan berikut ini.

Telinga kirimanmu sudah kuterima dengan baik. Sampai sekarang darahnya masih menetes-netes. Kupikir kenang-kenanganmu dari medan perang itu sesuatu yang luar biasa. Telinga itu kugantung di ruang tamu dan tamu-tamu mengaguminya. Aku sangat terharu engkau masih teringat padaku di medan perang yang hiruk pikuk itu. Engkau pasti sangat lelah bertempur setiap hari dan menembaki musuh sampai mati.... (Ajidarma, 2016, hlm. 15) 
Program Studi Pendidikan Bahasa dan Sastra Indonesia FKIP Universitas Kuningan

Berdasarkan kutipan di atas, tergambar bahwa ideologi teks sebagai kontradiksi IU dinarasikan atas fakta realitas, yaitu insiden di Dili, Timor Timur, yang menelan banyak korban jiwa. Dalam cerpen tersebut, teks berusaha mengungkap fakta yang dibungkam dan ditutup-tutupi oleh pemerintah. Artinya, fakta realitas tersebut berusaha dinaturalkan dalam teks sehingga tidak secara terang-terangan menyampaikan maknanya. Namun, teks tetap menyimpan hubungan yang paling signifikan dengan kenyataan (Whitehead, 1977:23). Pada gilirannya, cerpen "Telinga" menyelipkan ideologi teks sebagai wahana kritik dan resistensi terhadap manifestasi sosial dan budaya dari rezim otoriter Orba.

Sebagaimana telah diketahui dalam realitas rezim Orba, insiden di Dili merupakan peristiwa pembantaian secara keji terhadap orang-orang yang prokemerdekaan Timor Timur. Insiden tersebut setidaknya menelan 250 korban jiwa. Melalui realitas tersebut, cerpen "Telinga" ditransformasikan ke dalam teks yang secara estetik hadir melalui simbolsimbol. Hal tersebut tergambar dalam kutipan berikut ini.

"Alangkah kejamnya pacar Dewi itu," ujar Alina kepada juru cerita itu.

Maka, juru cerita itu pun menjawab, "Tapi, banyak orang menganggapnya pahlawan." (Ajidarma, 2016, hlm. 19)

Melalui kutipan di atas, ideologi teks hadir sebagai bentuk oposisi. Diksi "kejam" dioposisikan dengan diksi "pahlawan". Hal ini menimbulkan teks sebagai bentuk kritik terhadap dominasi IU. Dewanto (1993, hlm. 5) menyatakan bahwa fiksi SGA sebagai sesuatu yang penting, yaitu menyangsikan sesuatu yang dianggap sebagai kebenaran yang dibuatbuat (oleh rezim Orde Baru). Dalam hal ini, ideologi teks cerpen "Telinga" menghasilkan kritik dan semangat perlawanan untuk meraih keadilan dalam kehidupan berbangsa dan bernegara. Artinya, ideologi teks dalam cerpen "Telinga" berhasil dinaturalisasikan melalui ruang estetik untuk mengkritik dan mengungkap fakta yang disembunyikan pada masa Orba. Pada akhirnya, kritik cerpen "Telinga" yang dikonstruksi secara estetik berusaha menyampaikan fakta realitas yang terjadi pada masa Orba tanpa harus dibungkam oleh pemerintah.

\section{KESIMPULAN}

Berdasarkan hasil analisis terhadap cerpen "Telinga" karya SGA dengan pendekatan kritik sastra materialistis Terry Eagleton, penelitian ini sampai pada kesimpulan sebagai berikut.

Pertama, cerpen "Telinga" hadir melalui proses yang cukup kompleks di lingkaran Orba. Dalam hal ini, cerpen "Telinga" perlu melalui atau menerobos struktur produksi pada masa Orba. Pada masa Orba, corak produksi umum (CPU) didominasi oleh penguasa. Segala bentuk produksi diatur oleh pemerintah sehingga muncul ideologi umum (IU) represif yang berada dalam naungan ideologi Pancasila. Hal tersebut juga memengaruhi corak produksi sastra (CPS) yang dituntut propemerintah sehingga karya-karya sastra yang muncul berada dalam jalur tematik tertentu, seperti karya sastra bertemakan cinta. Keadaan demikian justru mengungkung pemikiran sastrawan yang tidak secara bebas dapat bersuara karena dominasi IU. Namun, justru dari hal tersebut, ideologi kepengarangan (IK) SGA hadir sebagai bentuk resistensi kepada pemerintah sehingga ideologi estetik (IE) dalam karya SGA, khususnya cerpen "Telinga", berbentuk kontradiksi dengan IU pada masa Orba.

Kedua, elemen internal (ideologi teks) cerpen "Telinga" hadir melalui pengaruh elemen eksternal teks yang 
Program Studi Pendidikan Bahasa dan Sastra Indonesia FKIP Universitas Kuningan

merupakan artikulasi dari kebijakan otoriter pada masa Orba. Pemanfaatan ideologi teks dalam cerpen "Telinga" juga berusaha menampilkan fakta realitas yang terjadi pada masa Orba. Oleh karena itu, ideologi teks yang muncul menghasilkan cerpen "Telinga" sebagai media kritik dan menghadirkan semangat resistensi untuk mencapai keadilan. Hal tersebut dihadirkan melalui simbol-simbol yang secara estetik muncul di dalam teks. Pada akhirnya, melalui ruang estetik, ideologi teks cerpen "Telinga" berhasil menghadirkan sebuah kritik untuk menyampaikan fakta realitas yang tidak tersampaikan pada masa Orba, sekaligus memantik resistensi terhadap rezim.

\section{DAFTAR PUSTAKA}

Ajidarma, S. G. (2010). Ketika Jurnalisme Dibungkam, Sastra Harus Bicara dalam Trilogi Insiden. Yogyakarta: Bentang Pustaka.

$$
\text { (2016). Saksi Mata. }
$$

Yogyakarta: Bentang Pustaka.

Akbar, S. A. (2019). Kritik Sosial atas Rezim Orde Baru dalam Kumpulan Cerpen Penembak Misterius Karya Seno Gumira Ajidarma: Kajian Sosiologi Sastra Marx. Jurnal Fonema, 2(2), 114-131.

Alderson, D. (2004). Terry Eagleton. England: Palgrave Macmillan.

Bennet, T. (2003). Formalism and Marxism. London: Routledge.

Dewanto, N. (1993). Cerpen-cerpen Terbaik Kompas 1992. In Pelajaran Mengarang: Cerpen Pilihan Kompas 1993. Jakarta: Kompas.

Djunuhi, M. S. (2020). Strategi Produksi dan Struktur Ideologi dalam Novel Perempuan Berkalung Sorban. Atavisme, 23(2), 175-188.

Eagleton, T. (1983). Function of Criticism. New York: Verso.
(1998). Criticism and Ideology: A Research in Marxist Literary Theory. New York: Verso.

Faruk. (2010). Pengantar Sosiologi Sastra dari Strukturalisme Genetik sampai Post-modernisme. Yogyakarta: Pustaka Pelajar. (2015). Metode Penelitian Sastra: Sebuah Penjelajahan Awal. Yogyakarta: Pustaka Pelajar.

Fuller, A. (2011). Sastra dan Politik: Membaca Karya-karya Seno Gumira Ajidarma. Yogyakarta: INSIST Press.

Heryanto, A. (1990). State Ideology and Civil Discourse. In Arief Budiman (ed.), State and Civil Society. Clayton: Centre of Southeast Asian Studies.

Kurnia, S. S. (2002). Jurnalisme Sastra. Jakarta: PT Gramedia Pustaka Utama.

Maier, H. M. J. (1999). Flying a Kite: The Crimes of Pramoedya Ananta Toer. In Vicente L. Rafael (ed.), Figures of Criminality in Indonesia, the Philippines and Colonial Vietnam. Ithaca: Southeast Asia Program Publications.

Purnamawati, Z., Sangidu, Manshur, F. M., dan Dardiri, T. A. (2019). Ideologi Perlawanan dalam Antologi Puisi $F \bar{\imath}$ Tarīqi Al-Fajri Karya Abdullah AlBaradduni. Poetika: Jurnal Ilmu Sastra, 7(1), 72-89.

Rampan, K. L. (2001). Angkatan 2000 dalam Sastra Indonesia. Jakarta: Kepustakaan Populer Gramedia.

Salam, A. \& Akmal, R. (2014). Pahlawan dan Pecundang: Militer dalam Novel-novel Indonesia. Yogyakarta: Gadjah Mada University Press.

Schwarz, A. (1994). A Nation in Waiting. St. Leonards: Allen \& Unwin.

Sunanda, A. (2015). Pandangan Masyarakat tentang Sistem Kekuasaan Sosial dan Politik. Jurnal 
Program Studi Pendidikan Bahasa dan Sastra Indonesia FKIP Universitas Kuningan

Kajian Linguistik dan Sastra, 27(2), 114-125.

Tempo, F. M. (2013). Kekerasan Personal dalam Cerpen "Jakarta, Suatu Ketika" Karya Seno Gumira Ajidarma. Jurnal Madah, 4(1), 2536.

Turama, A. R. (2016). Representasi Kekuasaan Negara dalam Cerpen Seno Gumira Ajidarma Sebelum dan Sesudah Reformasi: Analisis Gramscian. Jurnal Logat, 3(1), 1825.

Whitehead, John. (1977). Eagleton's 'Criticism and Ideology'. Oxford Literary Review, 2(2), 22-23.
Zamzuri, A. (2018) Cerpen "Matinya Seorang Penari Telanjang" Karya Seno Gumira Ajidarma dalam Perspektif Subjek Slavoj Žižek. Jurnal Aksara, 30(1), 1-16.

\section{Daftar Laman}

https://id.wikipedia.org/wiki/Seno_Gumir a_Ajidarma. Diakses pada 4 Oktober 2020, pukul 19.45 WIB.

https://id.wikipedia.org/wiki/Pembantaian

Santa_Cruz. Diakses pada 22 Januari 2021, pukul 10.15 WIB. 